\title{
A Critical Teacher Education Experience in the State of Goiás, Brazil ${ }^{1}$
}

\section{Uma experiência de formação crítica docente no estado de Goiás, Brasil}

Rosane Rocha Pessoa*

*Universidade Federal de Goiás (UFG), Goiânia - Goiás / Brasil

pessoarosane@gmail.com

Maria Eugênia Sebba Ferreira de Andrade**

**Instituto Federal de Educação, Ciência e Tecnologia de Goiás (IFG), Cidade de Goiás

- Goiás / Brasil

eugeniasebba@gmail.com

Edilson Pimenta Ferreira***

***Instituto Federal de Educação, Ciência e Tecnologia do Triângulo Mineiro (IFTM), Uberlândia - Minas Gerais / Brasil

edilsonferreira@iftm.edu.br

\begin{abstract}
One of the Brazilian government initiatives to improve basic education was to create the National Network of Continuing Education for Teaching Professionals of Public Basic Education in 2011. Our extension program in this network was implemented in 2013 in 10 towns of the state of Goiás and counted on 21 teacher educators and 110 teacher-participants. Part of the empirical material of one of these teacher educators will be analyzed in this article, focusing on the discourses of seven female teacher-participants about their previous language teacher education experiences and about the first two months of the extension course. The qualitative discussion draws on theorizations from Critical Discourse Analysis and Teacher Education in Brazil, and shows that discourses on language teacher education, English teaching, and English were problematized.
\end{abstract}

KEYWORDS: education policy; teacher education; English teachers' discourses.

\footnotetext{
${ }^{1}$ We would like to thank Fundação de Amparo à Pesquisa do Estado de Goiás (FAPEG) for financing the first author's trip to Geneva to present this paper in the 4th International Conference Applied Linguistics and Professional Practice. We are also very thankful to Viviane Pires Viana Silvestre, Marco Túlio de Urzêda Freitas, and Julma Dalva Vilarinho Pereira Borelli, participants of our study group Transição, who gave this text its last critical reading, and to Joyce Gracielle de Sousa Braga for the language review.
} 


\begin{abstract}
RESUMO: Uma das iniciativas governamentais brasileiras para aprimorar a educação básica foi criar a Rede Nacional de Formação Continuada dos Profissionais do Magistério da Educação Básica Pública em 2011. Nosso curso de extensão nessa rede foi implementado em 2013 em 10 cidades do estado de Goiás e contou com 21 professoras/es formadoras/es e 110 professoras/es participantes. Parte do material empírico de uma/um dessas/es professoras/es formadoras/es será analisado neste artigo focalizando os discursos de sete professoras participantes sobre suas experiências prévias de formação docente e sobre os dois primeiros meses do curso de extensão. A discussão qualitativa se fundamenta em teorizações da Análise de Discurso Crítica e da Formação Docente no Brasil e evidencia que discursos sobre formação de professoras/es de línguas, ensino de língua inglesa e inglês foram problematizados.
\end{abstract}

PALAVRAS-CHAVE: política educacional; formação docente; discursos de professoras de inglês.

\title{
Introduction
}

Teacher education has played a central role in the educational discourse in Brazil. Most basic public school teachers face a teaching ambiguity between professionalism and proletarianization, which imposes upon them a semi-professional condition (ENGUITA, 1991). This condition is understood as resulting from the process of the democratization of basic education, which began at the end of the 1960s. Nowadays, teachers, mostly women, have been facing the challenge of democratizing quality in basic education and transforming unfair social structures, as well as struggling against low salaries, the loss of professional prestige and status, and the lack of specialized knowledge. One of the government initiatives to cope with the need to improve basic education was to create the Rede Nacional de Formação Continuada dos Profissionais do Magistério da Educação Básica Pública (National Network of Continuing Education for Teaching Professionals of Public Basic Education) in 2011.

The first author of this article and Dr. Eliane Carolina de Oliveira from Universidade Federal de Goiás (UFG) proposed a project, entitled Projeto institucional de formação continuada de professores de inglês como LE/ adicional: UFG (Institutional Project of Continuing Education for Teachers of English as a Foreign/Additional Language: UFG), which was approved at the end of 2012 and implemented in 2013. The aim of the project was to have 475 English teachers as participants in 10 cities of the state of Goiás, a Midwest 
state of Brazil. However, only $110^{2}$ (86 female and 24 male) concluded the teacher education extension program of 120 hours, distributed throughout the year. The project sought to promote the following: the development of teachers' discursive competence in English; reflections on critical English teaching (PENNYCOOK, 1999, 2001; NORTON; TOOHEY, 2004; HAWKINS; NORTON, 2009; PESSOA; URZÊEDA-FREITAS, 2012), grounded on theoretical discussions and pedagogical issues; the problematization of naturalized practices and discourses regarding English, language education, teacher education, and social issues.

Underpinning these aims is the emerging paradigm of "prudent knowledge for a decent life" proposed by Santos (1988, p. 60), according to which "creating new knowledge is not enough; what is necessary is that someone be recognized in it"3 (SANTOS, 1997, p. 287). In this new paradigm, the school has a crucial ethical commitment to new generations; it is a citizen school, which proposes, in the name of criticality, the resumption of concepts such as justice, happiness, virtue, dignity, and solidarity. Utopia is also an important aspect of this paradigm, since it somehow influences people's disposition, making them not only imagine a better world, but also fight for it.

The 19 teacher educators (14 female and 5 male) involved in the course were aware that the public school context is adverse, but they were also aware that it offers a world of possibilities. In addition, six of these educators founded their rationale on critical perspectives, that is, they were aware that English is the language of domination and exclusion (PENNYCOOK, 2007), but also a language we can take ownership of in a critical and counter-hegemonic way (HOOKS, 1994). The second author of the present article was one of these six teacher educators. Part of the empirical material generated for her doctoral thesis will be discussed in this article, focusing on two analyses: (i) the discourses of her seven female teacher-participants regarding their previous experiences in language teacher education and regarding English; and (ii) the discourses produced in the

${ }^{2}$ There were 272 teachers enrolled in the course, but only 189 showed up on the first day. A big part of them gave up soon after the first class and a few of them quit along the course. We sent the dropouts a questionnaire to find out why they had quit, but we did not receive any answers.

${ }^{3}$ All the quotes that were originally written in Portuguese have been translated into English. 
first two months ( $1^{\text {st }}$ module) of the extension course, which resulted from the process of collaboration between the teacher educator and the teacher participants (hereinafter simply referred to as 'teachers').

\section{Discourses on teacher education}

This study draws on theorizations from Critical Discourse Analysis, given that teacher education is seen as a social practice and this concept encompasses the perspective not only of social structure, but also of social action and agency (FAIRCLOUGH, 2001). According to Fairclough (1992, p. 63), discourse is "a form of social practice, rather than a purely individual activity or a reflex of situational variables." This definition implies that discourse is a mode of action (people act upon the world and upon each other) and a mode of representation (systems of knowledge and belief). It also implies that there is a dialectical relationship between discourse and social structure, as occurs with social practice and social structure, with the latter representing "both a condition for, and effect of, the former" (FAIRCLOUGH, 1992, p. 64).

For Fairclough (1992), discursive practice contributes to reproduce social identities, social relationships, and systems of knowledge and belief, as well as contributes to the process of their transformation. Thus, one cannot see these discursive practices as closed structured places, but rather as places constitutively "invaded" by elements that originally pertain to other areas, other discursive formations. This author, therefore, assumes that, in contemporary debates, there is an emphasis on the constitutive properties of discourse. The same example he gives about family to show that "the discursive constitution of society does not emanate from a free play of ideas in people's heads but from a social practice which is firmly rooted in and oriented to real, material social structures" (FAIRCLOUGH, 1992, p. 66) can be brought to the context of teacher education, as it is partly constituted in discourse. However, three provisos block this discursive constitution: 1) the reified practices of language teacher education in Brazil with preexisting relationships and identities; 2) the combination of the constitutive effects of discourse work with those of other practices, such as teachers' working conditions, the distribution of tasks in these programs, and affective aspects of behavior; and 3) the constraints of the dialectical determination of discourse by social structures and of particular power relations and struggles. 
Fairclough (1992) points out that discourses are politically and ideologically invested, and can also be reinvested. According to him, this would lead to a cyclical clashing process of the reconstruction of subject. Hence, as a subject can only become a real subject through discourse, and discourse is part of a constant reformulation process, one can infer that the subject is always under reformulation. What this author suggests is that subjects play different roles in different contexts and, for some reason, they tend to mask this complex process in which they inserted by discontinuing the act of "becoming subject" and dislocating to the act of "becoming individual". This implies that not rarely do subjects disregard the coexistence of elements that are part of their referentiality and their remodeling.

These elements do exist and, as they are in constant alterity, we must not believe that one overlaps the other. What happens is that they are interpenetratedly and interconstitutedly part of their embedded ideology, and this is part of the continum of the subjects' discursive inscriptions. As such, we must admit that these elements are deemed absolutely essential, and one must credit reflection and stance to them. It is never enough to recall that ideology is seen by Fairclough (1992) as the means by which some people try to maintain or enhance their supremacy over others. Consequently, according to the author, behind the utterances that subjects enunciate, there are underlying reasons for doing so. These reasons are in accordance with the expected conditions of production and reception. Thus, subjects are in constant and continuing self-assessment of what they say, in such a way that they dislocate their utterances towards the expectations of the social audience.

In an analysis, two dimensions of discourse should be considered: the communicative event, which is an instance of language use (e.g. a lesson), and the order of discourse, which is the configuration of all of the discourse types used within a social institution or social field (FAIRCLOUGH, 1995, cited in JORGENSEN; PHILLIPS, 2002). Within an order of discourse, there are specific discursive practices through which text and talk are produced and consumed or interpreted (FAIRCLOUGH, 1995, cited in JORGENSEN; PHILLIPS, 2002). The interaction between teacher educator and in-service teachers in a teacher education course would be an example of a discursive practice.

An order of discourse in Brazilian education is teachers' proletarianization. According to Nóvoa (1995), the generic term emerged after the 1930s and 1940s, and it expresses the loss of teachers' professional 
autonomy - teachers became subjected to "new norms of teaching organization that tended toward the standardization of important processes, such as textbooks, centralized curriculum proposals, external evaluation, and so forth" (OLIVEIRA, 2004, p. 1134). This proletarianization resulted from the expansion of the school system in the post-war period, and the consequent easing of hiring requirements and the increase in teaching feminization. Feminine attributes, deemed as natural for children literacy and socialization, also contributed to feminine insertion in teaching, though it did not mean professional recognition, as it was considered to be an extension of household tasks. Nowadays, public basic education teachers face the teaching ambiguity between professionalism and proletarianization, which imposes upon them a semi-professional condition (ENGUITA, 1991).

Since the 1990s, with the imperative of globalization, the mainstream educational discourse in Latin American countries can be "summarized in a widely used expression in the studies produced by international entities belonging to the UN [United Nations] to guide Latin-American governments concerning education: productive transformation with equity" (OLIVEIRA, 2004, p. 1129). According to the author, the reduction of social inequities should be sought by expanding basic education, which would allow populations in vulnerable situations to find ways to survive. However, educational investments have not increased in the same proportion as this expansion has. On the other hand, with the legal requirement of democratic school management from 1988, the participation of teachers and the community in the development of policies for education has become a school management requirement. In this context, teachers are represented as crucial elements, as they are generally considered responsible for the performance of the students, the school, and the system. Thus, quite often they feel responsible for the success or failure of educational programs. In addition to these administrative requirements, they also see themselves forced to master new practices and knowledge in order to perform their duties, such as the project-based learning pedagogy, transversality, and formative assessment (OLIVEIRA, 2004). The author states that the studies she has conducted show that these requirements have made them helpless and insecure from both objective (they lack adequate working conditions) and subjective perspectives.

Monte Mór (2013a), a Brazilian Applied Linguist and one of the authors of the official document Orientacões Curriculares para o Ensino Médio: Linguas Estrangeiras (hereinafter Curriculum Guidelines for Secondary 
Education: Foreign Languages) (BRASIL, 2006), drawing on studies carried out in her research group, affirms that teachers are not familiar with the theme foreign language policies and do not seem to reinterpret global or national guidelines in a way that they contemplate what is local. She adds that they see themselves as implementers of planning policies that have not been decided by them and do not perceive there is room for exercising their agency or promoting engaged citizenship among their students. Based on Luke et al. (2013), Monte Mór (2013a, p. 229) defends teachers' “adaptive professionalism", through which teachers should develop more ability for syllabi interpretation and more engagement with the diversity of school contexts and students. According to the authors (cited in MONTE MÓR, 2013a), these abilities are crucial to improving teaching quality and reducing education inequality, but these can only result from investments in both preservice and in-service teacher development.

One of the aims of the extension course that we offered in 2013 was to provide in-service teachers with an experience of critical language teaching, which may have appeared to them as another new practice requirement, as mentioned by Oliveira (2004), but may also have given them the opportunity to understand the discursive practice of agency in the official documents of the field, which are grounded on Discourse Analysis, Critical Literacies, and Critical Pedagogies. These documents complement the most important law in education in Brazil, the Lei de Diretrizes e Bases da Educação Nacional (National Education Guidelines and Framework Law) (BRASIL, 1996), in which the conception of education is not limited to instruction; rather, it is perceived as a broad educational process:

\section{TITLE II}

Principles and ends of national education

Art. 2. Education, a duty of the family and the State, inspired in the principles of freedom and in the ideals of human solidarity, is aimed at the full development of the individual for the exercise of citizenship and preparation for work. (BRASIL, 1996, p. 1)

The law resulted from discussions, analyses, struggles, and the engagement of various social sectors, which had been excluded from democratic practice for at least 21 years (1964-1985) of authoritarianism, marked by "disrespect to human rights, income concentration, and economy denationalization" (OLIVEIRA et al., 2010, p. 46). Therefore, one can state 
that in every realm of society there was a call for legal changes that would allow for more freedom. This production condition seems to justify why this law was regarded as remarkably important for that period. Not only this general law, but also the other legal documents issued by the Ministry of Education concerning foreign languages have been seen as an attempt to break with traditional teaching in regular schools and meet the demands of grassroots classes. All of these focus on the students' political role in society. In Parâmetros Curriculares Nacionais: Lingua Estrangeira (National Curriculum Parameters for Foreign Language) (BRASIL, 1998), we highlight four objectives concerning this role. This document indicates that primary schools should aim to help students

- $\quad[c]$ omprehend citizenship as social and political participation, as well as the exercise of political, civil, and social rights and duties, adopting attitudes of solidarity, cooperation, and repudiation to injustices, respecting the other and requiring the same respect to him/herself.

- $[\mathrm{p}]$ osition themselves in a critical, responsible, and constructive manner in different social situations, using dialog as a means through which to mediate conflict and make collective decisions.

- $\quad[\mathrm{k}]$ now and value Brazilian sociocultural heritage, as well as sociocultural aspects of other peoples and nations, positioning themselves against any discrimination based on differences related to culture, social class, beliefs, sex, ethnicity, or other individual and social characteristics. (BRASIL, 1998, p. 7)

In the Curriculum Guidelines for Secondary Education: Foreign Languages (BRASIL, 2006), one of the aims is to reaffirm the relevance of the notion of citizenship and to discuss its practice in foreign language teaching. The term is explained as follows:

According to the traditional view, talking about citizenship means talking about homeland, civic duties, as in the old Civic Education classes. $[\ldots]$ Nowadays, $[\ldots]$ it is understood that "being a citizen" involves the understanding of which position/place a person (the student, the citizen) occupies in society. That is, from what standpoint does s/he speak? Why is it her/his standpoint? How did s/he come to this standpoint? Does $\mathrm{s} /$ he want to be there? Does s/he want to change it? Does s/he want to leave it? What does her/his standpoint include or exclude her/him from? In this perspective, the subject Foreign Languages can include citizenship development. (BRASIL, 2006, p. 91). 
The last document we want to point out here is the Politica Nacional de Formação de Profissionais do Magistério da Educação Básica (National Policy for Teaching Professionals of Basic Education) (BRASIL, 2009), which also has as one of its core purposes:

to promote teacher education in the perspective of holistic education, of human rights, of environmental sustainability, and of ethnoracial relations, aimed at building an inclusive and cooperative school environment.

These excerpts emphasize the importance of agency, which we believe can be fostered by readings on critical studies and discussions on relevant social issues in every school subject. Critical educational perspectives have been defended by other Brazilian teacher educators, such as Gimenez (2013), Jordão (2013), Menezes de Souza (2011), Monte Mór (2013b), Tílio (2013), Pessoa (2013), and Pessoa (2014), but our research participants did not seem to be aware of these discursive practices. According to Celani (2010), another known Brazilian teacher educator, this occurs because Brazilian educational authorities develop and distribute documents, curricular guidelines and materials for foreign language teaching which do not make sense to teachers, who are unprepared and unfamiliar with the theoretical approaches expressed in these texts. In the same perspective, Monte Mór (2013a, p. 221) states that, though the official documents recommend that teachers make alterations according to their contextual needs, she believes this rarely happens, as teachers "do not feel they have legitimacy" and are not "confident to exercise this sort of agency."

\section{Research context}

The empirical material used in this article was generated in a town called Cidade de Goiás (24,739 ${ }^{4}$ inhabitants), in the state of Goiás, Brazil, in March and April 2013. All the eight teachers travelled from smaller towns near Cidade de Goiás to take the course. Only the data of seven teachers will be analyzed here because one of them had never taught English. She was taking the course because she wanted to become an English teacher. The following chart shows the participant's profile:

\footnotetext{
${ }^{4}$ These data and those presented in Chart 1 are estimates for 2013, based on data supplied by the Instituto Brasileiro de Geografia e Estatistica (IBGE) (Brazilian Institute of Geography and Statistics).
} 
CHART 1: The participants' profile

\begin{tabular}{|c|c|c|c|c|c|}
\hline $\begin{array}{c}\text { Ficticious } \\
\text { Name }\end{array}$ & $\begin{array}{c}\text { Age in } \\
2013\end{array}$ & $\begin{array}{l}\text { Town and } \\
\text { Population }\end{array}$ & $\begin{array}{c}\text { Teaching } \\
\text { Experience }\end{array}$ & $\begin{array}{c}\text { English } \\
\text { Teaching } \\
\text { Experience }\end{array}$ & $\begin{array}{c}\text { Year and } \\
\text { Place of } \\
\text { Graduation }\end{array}$ \\
\hline Luz da Lua & 48 & Lua Nova: 565 & 26 years & 10 years & $\begin{array}{l}2000-U_{E G}^{5} \\
\text { Goiás }\end{array}$ \\
\hline Paula & 45 & Araguapaz: 7,513 & 20 years & Not informed & 2000 - UEG Goiás \\
\hline Friend & 43 & Faina: 7,064 & 20 years & 20 years & $\begin{array}{l}\text { Not informed- } \\
\text { UEGGoiás }\end{array}$ \\
\hline Hillary & 31 & Heitoraí: 3,571 & 9 years & 9 years & $\begin{array}{l}2001 \text { - UEG } \\
\text { Itapuranga }\end{array}$ \\
\hline Daya & 28 & Lua Nova: 565 & 7 years & 1 year & $\begin{array}{l}2005 \text { - UEG } \\
\text { Jussara }\end{array}$ \\
\hline $\begin{array}{l}\text { Phoebe } \\
\text { Victoria }\end{array}$ & 26 & Lua Nova: 565 & 5 years & 3 years & $\begin{array}{l}2011 \text { - UEG } \\
\text { Jussara }\end{array}$ \\
\hline Ariel & 23 & Lua Nova: 565 & 1 year & 1 year & $\begin{array}{l}2011 \text { - UEG } \\
\text { Jussara }\end{array}$ \\
\hline
\end{tabular}

Source: Empirical material generated by the second author of this text in 2013.

The teacher educator, the second author of this text, was 33 years old in 2013. Every week she travelled $140 \mathrm{~km}$ from Goiania to Cidade de Goiás to teach the course. As mentioned, she acted both as a teacher educator and as a researcher. Here is a chart of the activities she offered in the first module of the course, called "Collaborative Teaching", ${ }^{6}$ which aimed to reflect on the importance of interaction and collaborative activities in the process of English teaching and learning.

\footnotetext{
${ }^{5}$ Universidade Estadual de Goiás (State University of Goiás).

${ }^{6}$ This was the first of four modules the teacher educator chose to address. The three others were: "English Learning and Literature", "Critical English Learning", and "English Language Materials". We chose the first module because we wanted to analyze the participants' first reactions to the course.
} 
CHART 2: Activities of the module "Collaborative Teaching"

\begin{tabular}{|c|c|}
\hline Date & Activity \\
\hline $\begin{array}{l}03 / 11 / 2013 \\
1 \text { p.m.to } \\
5 \text { p.m. }\end{array}$ & $\begin{array}{l}\text { Presentation of the Course Project (UFG/MEC). } \\
\text { Presentation of the Course Plan: "Collaborative English Language Learning". } \\
\text { Flower dynamic: Personal Presentation. } \\
\text { Written production: "Narratives about their professional stories" (finished at } \\
\text { home). }\end{array}$ \\
\hline $\begin{array}{l}03 / 22 / 2013 \\
1 \text { p.m.to } \\
5 \text { p.m. }\end{array}$ & $\begin{array}{l}\text { Brief explanation of the Course Project and the Course Plan to the new } \\
\text { students. } \\
\text { Group discussion using excerpts from the texts "Collaboration", } \\
\text { "Conversation", and "Conflict" by bell hooks. } \\
\text { Discussion on the video transcription: "The Danger of a Single Story" by } \\
\text { Chimamanda Adichie. } \\
\text { Homework: questions about the video. }\end{array}$ \\
\hline $\begin{array}{l}04 / 05 / 2013 \\
1 \text { p.m.to } \\
5 \text { p.m. }\end{array}$ & $\begin{array}{l}\text { Homework review: sharing the answers. } \\
\text { Song activity: "Reach", by Gloria Estefan (listen to the song, fill in the gaps, } \\
\text { produce a poster about your job dreams and write a poem (collaboratively) } \\
\text { about your job dreams. } \\
\text { Homework: Research about "Collaborative Learning" (definition, principles, } \\
\text { and personal opinion about the topic). }\end{array}$ \\
\hline $\begin{array}{l}04 / 12 / 2013 \\
1 \text { p.m.to } \\
5 \text { p.m. }\end{array}$ & $\begin{array}{l}\text { Reading: "Paulo Freire's Biography". } \\
\text { Video: "Reading the world" - Group discussion about the video. } \\
\text { Group discussion based on some parts of the book "Pedagogy of autonomy". } \\
\text { Homework (writing): "How can I help my students to become independent/ } \\
\text { autonomous?" }\end{array}$ \\
\hline $\begin{array}{l}04 / 19 / 2013 \\
1 \text { p.m. to } 5 \text { p.m. }\end{array}$ & $\begin{array}{l}\text { Homework review: sharing the answers to the question. } \\
\text { Pre-video activities. } \\
\text { Video/film: "Freedom writers". } \\
\text { Guidelines for the film analysis. }\end{array}$ \\
\hline $\begin{array}{l}04 / 26 / 2013 \\
1 \text { p.m.to } \\
5 \text { p.m. }\end{array}$ & $\begin{array}{l}\text { Discussion on the film (focus on the collaborative learning strategies). } \\
\text { Instructions on lesson plan. } \\
\text { Activity: "developing a lesson plan based on collaborative learning strategies and } \\
\text { on your students' needs" (finished at home). }\end{array}$ \\
\hline $\begin{array}{l}03 / 05 / 2013 \\
1 \text { p.m.to } \\
5 \text { p.m. }\end{array}$ & $\begin{array}{l}\text { Presentation of the lesson plan and its application in their classrooms. } \\
\text { Activities about the text "No Speak English", by Sandra Cisneros: focus on } \\
\text { language resistance. } \\
\text { Homework: Write another ending to the story (What happened with Mamacita } \\
\text { and her family some years later?). }\end{array}$ \\
\hline $\begin{array}{l}17 / 05 / 2013 \\
1 \text { p.m. to } \\
5 \text { p.m. }\end{array}$ & $\begin{array}{l}\text { Sharing the ending of the stories. } \\
\text { Evaluating the module. } \\
\text { Reflexive session about the module. }\end{array}$ \\
\hline
\end{tabular}

Source: Empirical material generated by the second author of this text in 2013. 
The empirical material encompasses an initial questionnaire (IQ), written narratives about the participants' teacher education and professional profiles (WN), a class activity titled "job dreams" (CA), questionnaires about the lessons (QL), a reflective session at the end of the module (RS), and a final questionnaire (FQ). Except for the class activities, the empirical material was generated in Portuguese; therefore, the analysis the teachers' speech are translated into English, but we have tried to be as faithful to the original as possible. Moreover, their speech in English that sounded ungrammatical to our ears was adapted, so as to avoid more constraints concerning their difficulties with English than those that are mentioned by them in the discussion sections of this article.

The following chart shows the documents we had received by the end of the module. Even though Paula and Friend did not participate in all the research documents, what they wrote was considered relevant for our discussion:

CHART 3: Research documents

\begin{tabular}{|l|c|c|c|c|c|c|c|}
\hline Documents & $\begin{array}{c}\text { Luz da } \\
\text { Lua }\end{array}$ & Paula & Friend & Hillary & Daya & $\begin{array}{c}\text { Phoebe } \\
\text { Victoria }\end{array}$ & Ariel \\
\hline Initial questionnaire & $\checkmark$ & $\checkmark$ & $\checkmark$ & $\checkmark$ & $\checkmark$ & $\checkmark$ & $\checkmark$ \\
\hline Written narratives & $\checkmark$ & $\checkmark$ & $\checkmark$ & $\checkmark$ & $\checkmark$ & $\checkmark$ & $\checkmark$ \\
\hline Class activity "Job Dreams" & $\checkmark$ & - & - & $\checkmark$ & $\checkmark$ & $\checkmark$ & $\checkmark$ \\
\hline $\begin{array}{l}\text { Questionnaires about the } \\
\text { lessons (a total of 6) }\end{array}$ & 6 & 1 & 1 & 6 & 6 & 6 & 6 \\
\hline Reflective session & $\checkmark$ & - & - & $\checkmark$ & $\checkmark$ & $\checkmark$ & $\checkmark$ \\
\hline Final questionnaire & $\checkmark$ & $\checkmark$ & $\checkmark$ & $\checkmark$ & $\checkmark$ & $\checkmark$ & $\checkmark$ \\
\hline
\end{tabular}

Source: Empirical material generated by the second author of this text in 2013.

In the following sections, the empirical material is discussed focusing on three themes: discourses on language teacher education, alternative discourses on teaching English, and alternative discourses on English.

\section{Discourses on language teacher education}

Language teacher education in Brazil - both university ${ }^{7}$ and ongoing teacher education - is normally discursivized as "failure", on the part not

\footnotetext{
${ }^{7}$ The term "university teacher education" is used instead of "pre-service teacher education" because some of the teachers had taught before entering university.
} 
only of teacher educators (LEFFA, 2001; COX; ASSIS-PETERSON, 2008; CELANI, 2010), but also of teachers and students. Cox and AssisPeterson (2008, p. 29), in an article entitled "The drama of English teaching in Brazilian public school", provide a historical overview of the place of English in Brazilian education since the 1960s, concluding that, though laws and official documents from the 1990s have aimed at "heralding a new era in foreign language teaching", they have had no influence on the "chronic crisis of foreign language teaching". In the last section of the article, they say that this drama should be fought by school teachers themselves, but first some basic conditions must be created: school teachers should have better salaries; the foreign language should have the same number of hours as the other school subjects; teachers must be protagonists of their pedagogical practice; and university teacher educators should act in order to end doubledegree courses (they aim at educating teachers of both Portuguese and a foreign language in a period of four years or less), should prepare proficient students, should forge closer ties between the university and the schools, and should develop research "with" the teachers, not "about" them.

According to Celani (2010, p. 61), the results of university language teacher education are "disappointing". She also attributes the failure to the fact that most of them are double-degree courses and postulates, in the same line of thought as Cox and Assis-Peterson (2008), that, in these courses, students do not often become proficient in the foreign language, do not learn crucial theoretical discussions, and do not have a good practicum experience. She adds that, as university education is "inadequate and insufficient" (CELANI, 2010, p. 61), teachers are not prepared to teach, and "foreign language is not learned at school" (CELANI, 2010, p. 61).

This discursive order of the lack of identification, disappointment, insufficiency, and lack of belonging is represented in the discourses of our research participants. They were asked to write a narrative of their English teacher education, but none of them wrote more than one page, which might show that they did not want/have time to write a detailed narrative or did not have much to say. Their discursivities about getting a degree in English and Portuguese teacher education (Letras: English and Portuguese ${ }^{8}$ ) have to do with discourses of individual and context constraints, most of which mingled with discourses of individual accomplishment:

${ }^{8}$ Hereinafter Letras. 
Luz da lua: I started to attend lessons [at university] hoping that I would learn English very well. Sweet illusion! May my ex-teachers forgive me, but except for some teaching techniques and strategies, the content of the courses was the same as the content I used to teach my school students. I learned a single word "eggplant" [...] and, not to be unfair, a teacher insisted on teaching us "pronunciation key according to The International Phonetic Association". I know it's important, but I refused to learn those symbols. I expected and wanted much more [from the course]. [...] I felt fulfilled with my students the way I could. (WN)

Paula: I faced many difficulties with English, but it did not prevent me from finishing the course. (WN)

Friend: In my course, I faced many difficulties, but I'm Brazilian, and I never give up. (WN)

Daya: The University didn't make me reach my goal [speaking English fluently], but I learned the basics. (WN)

Phoebe Victoria: I always thought I didn't know anything. That's how I started and left university, especially in the area of English language. [...] I had teachers who motivated and humiliated me. To the ones who motivated me, thanks! I also thank the ones who discouraged me, because bumiliation and criticism made me feel stronger and show my capacity. If I say I didn't learn anything I'd be lying, but most of my achievements resulted from my pedagogical practice. (WN)

Ariel: In the first year, I had a professor who had a Masters degree in English. My colleagues and I were completely fascinated [...] I learned a lot. [...] In the second year, I had an awful professor, who [...] humiliated everybody and didn't make much effort to make us learn. [...] Studying with bim was traumatizing, but I survived and won. (WN)

Hillary was the only participant who had a different opinion on her undergraduate course: "[At university] I had a great teacher who made me love English even more, and I dedicated myself to learning. I also took a specialization course in English Language" (WN). Though the limitations are obvious in the other participants' discourses, their agency is also evident in the following excerpts: "I'm Brazilian, and I never give up", "most of my achievements resulted from my pedagogical practice", "I only felt fulfilled with my students the way I could", and "I survived and won". 
The information in Chart 1 shows that three of them (Luz da Lua, Paula, and Friend), started teaching long before entering university, though only one had had pedagogical training in secondary school, and it seems from their accounts that they did not have many career choices. This can also be perceived in Hillary's account: "I have always lived in Heitoraí. Because it's a small town, and due to my family's financial condition, I opted to take Letras" (WN). The fact that they are female, live in small towns, and belong to the lower middle class reveals the close association of gender, class, and teaching highlighted by Apple (1998), according to whom the feminine nature of the teaching profession is related to the historical changes in the sexual division of labor and in the patriarchal and class relations. Nóvoa (1991, p. 126), who makes a comprehensive analysis of this process, states that

the feminization of the teaching staff in primary education is a phenomenon that, in spite of the specificities of each country, can be perceived in Western societies after the mid-nineteenth century, and contributes to a relative devaluation of the teaching profession.

This lack of choice and their unsatisfactory teacher education may be sufficient reasons why they avoid representing themselves as English teachers in the data. Another reason is that they had a degree both in English and in Portuguese, and three of them (Paula, Phoebe Victoria, and Ariel) had to take on English lessons only to complete their class load - which is another aspect of teaching proletarianization. Among the other four who really chose to teach English, Hillary affirms that she liked "teaching Portuguese best because the students value this language more than English" (WN), and Luz da Lua said she "had many interruptions", as she "had to take on other duties at school such as pedagogic coordinator and school principal" (WN). All this explains the vagueness in their answers to two questions of the Initial Questionnaire: What kind of teacher are you? and How do you teach?

\section{Alternative discourses on English teaching}

Discourses of failure and fluid professional identities were dominant in the data generated in the beginning of the extension course. The course sought to constitute an alternative discourse that is present in official documents concerning foreign language teaching: the discourse of critical perspectives. In the first research documents, there was only one reference to 
it, made by Hillary, when she talked about her motivation to take the course: "To become more critical, to position myself better in education". This was the statement that most related to the course aims, though we doubt whether what she meant by "critical" concerned the relationship of "properties of discourse interactions and texts with features of their social and cultural circumstances" (FAIRCLOUGH, 1999, p. 79), or referred specifically to unequal social conditions (PENNYCOOK, 2001), as we understand it.

The teacher educator tried to make these public school teachers aware of these critical perspectives by problematizing some social issues. The first text the teacher educator chose to work with was the video "The danger of a single story" by Adichie (2009). In the questionnaire about the activity, the teachers highlighted the relevance of the content, following this line of thought:

Daya: The text shows how dangerous it is to absorb and reproduce single concepts that the media shows about different countries, peoples, or cultures; it teaches us not to pre-judge, but to find out the truth about what we hear, to discuss the problems that are masked, to talk about themes that many people pretend not to exist. (QL)

The following theme was "job dreams", which is relevant here because most of the teachers related language to action, as it can be seen in these two answers to the question "Do you find these activities relevant to your professional practice? Why?":

Hillary: In the beginning I didn't, but later I perceived that when dreams are similar, it means that we want to change our professional life. That is, we want to act in an innovative way. (QL)

Phoebe Victoria: I find them relevant, since talking about our dreams encourages us to search for what is better and to make them come true. (QL)

In a poster describing their dreams, most of them were associated with language (following section), but they also mentioned dreams concerning teaching, students, working conditions and profession: teaching better, using methods that include everyone, respecting the students' individuality, having more diligent students, having better school facilities, having more English lessons and fewer students in class, and being valued in society. 
The following theme was Paulo Freire's life and ideas. In the questionnaires, there were vague comments, such as "The activity was interesting, because we've learned about Freire's life and ideas about education, which are still relevant today" (Ariel/QL). Among them, two answers indicate that they were reflecting on their agency:

Hillary: [Paulo Freire] struggled a lot, and I think that we also struggle, and we are also looking for strategies to teach better. This activity was good because it started to take me out of the conformism imposed by the system. (QL)

Daya: [Paulo Freire] has shown that, if we believe it and dedicate ourselves, we can change lives. (QL)

The film "Freedom Writers" was watched in the following class, and it yielded the most enthusiastic reactions and the most relevant reflections, most of which were concerned with taking action to promote "change", a word which is present in most of these excerpts:

Luz da Lua: [It] fed our hope that human beings can change their behavior when appropriately encouraged. (QL)

Paula: [It] shows we can contribute to change our students. We just have to believe they are capable and let them build knowledge from their realities. [...] This activity makes us reflect and change our teaching. We have students who have learning difficulties, family, social, and racial problems, so we have to be more responsible and try to help them overcome their difficulties and reach their objectives. (QL)

Friend: [It] showed we are capable of overcoming prejudice barriers and reaching our aims. [...] It showed that, as a teacher, I have to deal with conflicts without losing control. (QL)

Hillary: [...] we can see that school contexts are the same, and wherever we are, we can have difficult situations, but, by doing simple things, we can contribute to our students' success. (QL)

Phoebe Victoria: [It] awoke our determination and will to change our students' reality. (QL)

Ariel: $[1 t]$ made us see a class reality and encouraged us not to give up and to fight prejudice. (QL) 
Next, they had to prepare a critical and collaborative lesson plan and put it into practice in their own classes. However, the questionnaires show that the lessons had good results in terms of participation and interest on the part of their students, but they do not give many details about what was done. On the other hand, at the end of the module, all of them mentioned they had put into practice many activities done in the course. An emphasis was given to the recognition of the students as active class participants and social subjects:

Paula: I learned the importance of interaction among individuals for knowledge construction and skills development. With Paulo Freire, I learned that the teacher has to respect the students, especially the ones from grassroots classes. (FQ)

Friend: I learned that I should promote the students' participation, as I'm only a mediator of knowledge, not the truth owner. I've learned a lot from my students' experiences in class. (FQ)

Hillary: The course made me value my student. I always worried about them, but, because I'm impatient, I don't give them time to discuss their ideas. [...] We learned to give students voice and to give voice to ourselves. Here we share anxieties, difficulties, successes we've reached in our lessons, and we're valued. (FQ)

Daya: We've learned to treat our students differently, to know them better. It made me feel bad because I felt responsible for all of them. (RS)

Phoebe Victoria: Collaboration brings the students' experiences and social context to the classroom, and it makes them learn more. At the end of the module, I believe I have a new way of teaching, and the students are enjoying it. (RS)

Ariel: The course has helped me to respect my students. [...] Now I've been really experiencing what a lesson is. [...] I find it interesting to learn a word with them [the students]. They feel we are together. This companionship we are learning here is valuable. (RS)

The fact that they repositioned their students may reflect the teacher educator's attitude and practice throughout the course. In the two final research documents, she is described as "simple", "humble", "competent", "dedicated", "patient”, "polite, but firm", "delicate, but strong”, having "respect for everybody", and "not discriminating anybody". The teacher 
educator's position has been constituted by the order of discourse, which has characterized the official documents and the specialized literature about language education. As shown, the participants have emphasized the students' political role in society and the teachers' commitment to the ideals of solidarity, so well summarized by what Santos (1988, p. 60) calls "prudent knowledge for a decent life". This is also reinforced by some of the teachers, who seemed to have seen the importance of working with critical issues:

Luz da Lua: I share ideas about collaborative learning and discuss attitudes concerning controversial issues such as prejudice/ discrimination, among other social problems, with my colleagues so that they can improve their practices. (FQ)

Hillary: The activities were diverse and creative. We could question and develop critical thoughts about our context, and I love it. (FQ)

Phoebe Victoria: I'm more aware of a more critical way of teaching, which can educate citizens capable of acting in this society. [FQ)

Ariel: The first module was very productive because we had the opportunity to see our teaching differently, aimed at the teachers' and the students' criticality. [...] We talked about prejudice, discrimination, and other social problems. (FQ)

From all the accounts presented in this section, we can say that, in general, they have grasped an important aspect of critical approaches to teaching: that problem-posing can make learning relevant if problematic issues in learners' lives are addressed. Though Daya's speech, "It made me feel bad because I felt responsible for all of them," reminds us of what Oliveira (2004) pointed out about teachers not being ready to respond to new pedagogical requirements, we believe we have to be prepared to understand that the school has a crucial ethical commitment to new generations (SANTOS, 1988).

\section{Alternative discourses on English}

In the written narratives and the initial questionnaire, we can notice that the discourses of seven participants about English are concerned with enchantment/desire, as we can learn from their lexical choices. Luz da Lua said her interest started with her first contact with the language and, after reading the book "A trip to the Moon", she was fascinated, but now she 
continues searching "to satiate the great desire that makes her heart tick to learn how to listen, speak, read, and write in English satisfactorily." Hillary stated she had always loved it since the first contact. Daya affirmed she found the course [referring to the course we offered in 2013) of her dreams because it awakens her interest a lot by the most known language in the world. Phoebe Victoria and Ariel stated that they really like the language. Friend also affirmed she likes English. Paula was the only participant who did not affirm she likes English in any of the research instruments. She argued that teaching English is "a personal challenge".

Psychoanalytically speaking, this strong attraction to the language can be explained as "the desire of the other, this other who constitutes us and whose access is interdicted" (CORACINI, 2003, p. 149). This is what Bakhtin (1997) would call "alterity". According to the author, a person is constituted and constituent of the other, and, therefore, we may not think of language as a one-way process. Learning a language in this perspective is searching for the strange, the other, the different. This other that inhabits our participants is also the English teacher that they desire to be, characterizing their identities as heterogeneous and moving. None of them is an English teacher because they had learned English or had had a good teacher education, which can be seen in the following answers to two questions of the initial questionnaire: (1) Why are you an English teacher? and 2) What do you expect from this course?:

Luz da Lua: 1) I admire this language and know how necessary it is to speak a second language. I took Letras only because of English, but it let me down because I didn't learn as much as I wanted and needed, so I got frustrated. 2) To learn more, to address some of my weaknesses and share my experiences with the group.

Paula: 1) Because I took a university course and also because it is a personal challenge. 2) To overcome my difficulties and be able to perform my profession with more confidence.

Friend: 1) I am an English teacher because I like English. 2) I hope to improve my academic knowledge in the area.

Hillary: 1) I love teaching English; I like the strategies we can use to teach. 2) To become more critical, to position myself better in education and to learn the language better. 
Daya: 1) I'm very interested in speaking English fluently and learn it to teach my students, who already have experience with the language. 2) Make my classes more dynamic and improve my knowledge of the language.

Phoebe Victoria: 1) I like this language very much; I think it is important to know a second language and English is in evidence at the moment, so it is necessary to make students aware of it. 2) To learn more than grammar rules, which is what I studied at the university and in other courses. I want more knowledge.

Ariel: 1) I really like this language and that's why I took Letras. In class, I can learn and teach my students. 2) To learn teaching techniques to motivate my students and, if possible, to improve my speaking, because I need it, and I like it.

This desire gave room to fear as soon as the teacher education course started. As it aimed to make public school teachers aware of these critical perspectives by problematizing some critical issues using the English language, the first video the teacher educator chose to work with, as mentioned before, was that by Adichie (2009). As they had difficulty understanding the video, they read parts of the video transcript in class and discussed them. In the questionnaire about the activity, many answers focused on the relevance of the content (as pointed out in the previous section), but three teachers also focused on language aspects:

Luz da Lua: I confess I had some difficulties due to my poor education. I found some words strange, so I had difficulty organizing some sentences.

Hillary: The activity was great, but in the beginning I was very nervous. I had not been in contact with English for four years. When we started [reading], it seemed I couldn't understand a thing and neither could my colleagues. Everybody's face looked uncertain, insecure, and confused. Everybody felt ashamed of reading. We didn't know each other. I found the activity heavy to start with, but it was great.

Daya: Unfortunately, the text frightened us a bit because of its length and the amount of difficult words that our poor education didn't allow us to learn. Certainly, it served as a diagnosis to the teacher [teacher educator], who did not know our level of English yet. In the next edition of the course, a text like this should be worked later, when there is greater familiarity among students and teacher. 
Hillary's analysis of the group's reaction is meaningful, because language was such a big constraint that only two teachers (Hillary and Daya) turned up for the following class, and the course would have been discontinued if these two teachers had not persuaded some teachers to continue and invited others to join in. Throughout the eight meetings, the use of the target language is mentioned in some answers to the questionnaires about the activities, either emphasizing speaking or listening difficulties or the relevance of its use in the course. In the poster describing their dreams, most of them concerned language: learning English well and having their students speaking English.

Two accounts drew our attention since the teachers perceived a nonhegemonic language perspective in two videos shown: Chimamanda Adichie, a Nigerian woman, speaking in a TED talk (a nonprofit organization devoted to spreading ideas of people from every discipline and culture who seek a deeper understanding of the world) and Paulo Freire giving an interview conducted at the 1996 World Conference on Literacy organized by the International Literacy Institute, Philadelphia, USA. Listening to Adichie and Freire made them understand they can become real subjects through discourse:

Hillary: We always see only Americans talking in language courses. Seeing a Nigerian [Adichie] talking, presenting her thoughts to the whole world was fantastic. It made me value myself as a teacher, in a small city. I have to be proud, to defend my values and have voice, but being careful not to get frustrated.

Daya: [The interview with Paulo Freire] showed that even somebody with a strong Northeastern accent can speak English.

The teachers' subjectivity was also awoken when they read the short story "No speak English" by Cisneros (1991). This story shows a fat Mexican woman (Mamacita) who has recently arrived in the US and refuses to assimilate. She never leaves her room and she does not speak English, so when her baby boy starts speaking English, it breaks her heart. The teachers related to Mamacita's resistance to and difficulty with the language, emphasizing the importance of reacting against it: 
Luz da Lua: [The activity] made us reflect on the importance of the language and on its use.

Hillary: [The activity] made us reflect and compare it to our practice. $[\ldots]$ we noticed that the idea was to make us help ourselves and our students who resist learning the language.

Phoebe Victoria: The activity made me want to learn more, as the character was resistant to learning the language. It shows that we have to motivate our students to learn and to use English.

Ariel: The text shows what we experience in class, i.e., not only the students but also the teachers have difficulty in the language.

Daya had a different interpretation, as she related teachers to Mamacita and students to the baby boy:

Daya: ... she [we believe she is referring to the author of the short story] talks about the difficulty in learning English, the fear of taking risks and that this language is everywhere, so we can't ignore it. Our students must be conscious of it, and according to the text, these obstacles don't exist for them.

In brief, two main discourses concerning language characterized the first module: the discourse of difficulty and the discourse of possibility. These discourses are reiterated at the end of the first course module:

Luz da Lua: In the beginning of the course I was shocked with my English. (FQ)

Luz da Lua: In the first meeting, I was like: "My God! What am I doing here?" I was ashamed, the teacher was very competent and so was Hillary. But then I said, "I've learned some things, I've taught, I took Letras, so I'll face this challenge. (RS)

Paula: Throughout the course, I had a lot of difficulty to understand the teacher because she only spoke English and it made me scared, but I knew I had to overcome my difficulties and continue. (FQ)

However, as the authentic use of English in class appears as the biggest shock, it was also represented as the biggest gain of the first module, possibly even surpassing the gains concerning teaching: 
Hillary: My expectations about the course were not the best because I've been in the state school for 9 years, and the courses offered by the government are shameful due to the poor teaching quality. I thought I'd take part in the first meeting and wouldn't come back. What happened was that in the first meeting I noticed it would be different [...]. The course is given in English and, though it is difficult, it's great for us. (FQ)

Daya: I really didn't expect to find what I've found. The school and university education I had before was very traditional, aimed at grammar $[. .$.$] I'd never worked with language itself [. .$.$] the work with songs for example,$ Maria Eugênia made us complete, understand, find out the main ideas. She used them as texts. [...] We really learned English and how to make our lessons more dynamic in any subject. (RS)

Daya: I've learned that studying a language is much more that deciphering its codes or interpreting texts. I've learned it's an instrument of power and, thus, it has to be fought for. [...] I've learned we have to provoke students so that they can speak, that is, we have to give them voice. (FQ)

Phoebe Victoria: The course was different from everything I had seen. All I'd seen in my life were English grammar lessons. I'd never thought I could make my students use the language, speak, and write in the language. I'd always worked with decontextualized grammar because this is the way I was taught. [...] I never thought I would arrive here and see everybody speaking English. I thought: "My God! What am I doing here?" But I like challenges, so I said: "I will continue, I want to continue!" (RS)

Ariel: The course is different from everything I've seen so far. In the beginning, I confess it [the use of English] was shocking. (RS)

Their accounts show that traditional discursive practices about language were problematized. They may not have understood that English is the language of domination and exclusion (PENNYCOOK, 2007) or that discourse is a form of social practice (FAIRCLOUGH, 1992, p. 63), but they may have become suspicious, by watching Adichie and Freire speaking English, that we can take ownership of language in a critical and counterhegemonic way (HOOKS, 1994).

\section{Final remarks}

The discursive practices of the first module of the extension course were an attempt to oppose the order of discourse in the area of English teacher education, represented in words such as "drama", "chronic crisis", 
“disappointing", "inadequate”, "insufficient”, "sweet illusion”, "difficulties”, "humiliation", "criticism", and "traumatizing". Though teacher educators think of this "drama" in a broader perspective, six of the research participants focused on the fact that they had not learned how to speak English fluently, as it was represented as a dream in a class activity. However, when faced with the opportunity to use English in a teacher education course, their first reaction was to quit. After the "shock", they became engaged and questioned traditional discursive practices about content, teacher-student relationship, and language, that is, their accounts highlight the relevance of problematizing issues concerning the students' reality, the importance of interaction to knowledge construction, and the recognition that the use of English constituted the biggest shock in the course, but also the biggest gain they had.

It is worth noting that they are interpellated by other discourses, the most striking of which is agency, observed in many of their discursive and non-discursive practices: they received a degree in Letras; four of them became English teachers, three of them took on English teaching (even though they did not want to be English teachers); they decided to take the teacher education course (even experiencing lots of setbacks such as travelling every week on rough roads with no financial aid); and a great deal of their accounts show their wish to change and to make a difference. By no means can we discard the social audience for which the texts were produced. They were producing data for their teacher educator who travelled longer than them to teach the course and who had made it clear that the course was the context of her doctoral research. We also wonder why Paula and Friend did not hand in more than half of the research documents. Does it mean resistance? What did they refuse to say?

We are also aware that a 32-hour module was certainly not enough to alter much their competence in the language or make up for the poor teacher education they had, but the negotiations held in class may have somehow affected their professional positions, which are constantly reformulated. The course continued up to the end of 2013, and Andrade (2017) told us the rest of this story, which certainly did not finish with the end of the course. As a matter of fact, more than teacher education courses are necessary to change the order of discourse of teacher proletarianization in Brazil. 


\section{References}

ADICHIE, C. The danger of a single story. TEDGlobal. 2009. Available at: $<$ http://www.ted.com/talks/chimamanda_adichie_the_danger_of_a_single_ story>. Retrieved on: 28 jun. 2017.

ANDRADE. M. E. S. F. de. Formação continuada crítica de professoras de inglês como lingua estrangeira/ adicional: problematização de discursos e constituição ética dos sujeitos. 2017. 197 f. Doctoral Dissertation (Ph.D. in Letters and Linguistics) - Universidade Federal de Goiás, Goiânia, 2017.

APPLE, M. Ensino e trabalho feminino: uma análise comparativa da história e da ideologia. Cadernos de Pesquisa, Fundação Carlos Chagas, n. 64, p. 14-23, 1998. ISSN: 0100-1574, e-ISSN: 1980-5314.

BAKHTIN, M. Estética da criação verbal. 2. ed. São Paulo: Martins Fontes, 1997. [Original de 1979].

BRASIL. Ministry of Education and Culture. LDB - Lei no 9394/96, from 20 December 1996. Established the guidelines and bases of National Education. Brasília: MEC, 1996.

BRASIL. Ministry of Education. Department of Fundamental Education. National Curriculum Parameters: $3^{\text {rd }}$ and $4^{\text {th }}$ cycles of fundamental education: Foreign Language: MEC/SEF, 1998.

BRASIL. Ministry of Education. Department of Fundamental Education. Curricular Guidelines for High School: Languages, Codes and their Technologies: Brasilia: MEC/SEF, 2006.

BRASIL. Office of the Presidency. Civil Office. Deputy Leader of Legal Affairs. National Policy for the Education of Elementary School Teachers in Basic Education. Brasília, 2009.

CELANI, M. A. A. Perguntas ainda sem resposta na formação de professores de línguas. In: GIMENEZ, T.; MONTEIRO, M. C. de G. (Org.). Formação de professores de lingua na América Latina e transformação social. Campinas, SP: Pontes Editores, 2010. p. 57-67.

CISNEROS, S. The house on Mango Street. 2. ed. New York: Vintage Contemporaries of Random House, 1991.

CORACINI, M. J. R. F. Língua estrangeira e língua materna: uma questão de sujeito e identidade. In: CORACINI, M. J. R. F. (Org.). Identidade e discurso: (des)construindo subjetividades. Campinas: UNICAMP, 2003. p. 139-160.

COX, M. I. P.; ASSIS-PETERSON, A. A. O drama do ensino de inglês na escola pública brasileira. In: ASSIS-PETERSON, A. A. (Org.). Linguas estrangeiras: para além do método. São Carlos: Pedro \& João Editores/Cuiabá: EdUFMT, 2008. p. 19-54.

ENGUITA, M. F. A ambigüidade da docência: entre o profissionalismo e a proletarização. Revista Teoria \& Educação, Porto Alegre, n. 4, p. 41-61, 1991. 
GIMENEZ, T. Conversa com Telma Gimenez e Vilson J. Leffa. In: SILVA, K. A. da; ARAGÃO, R. C. (Org.). Conversas com formadores de professores de linguas: avanços e desafios. Campinas, SP: Pontes Editores, 2013. p. 349-359.

FAIRCLOUGH, N. Discourse and social change. Cambridge: Polity Press, 1992.

FAIRCLOUGH, N. The dialectics of discourse. 2001. Available at: <https://www. sfu.ca/cmns/courses/2012/801/1-Readings/Fairclough\%20Dialectics\%20of\%20 Discourse\%20Analysis.pdf>. Retrieved on: 28 June 2017.

FAIRCLOUGH, N. Global capitalism and critical language awareness. Language Awareness, Taylor \& Francis Online, v. 8, n. 2, p. 71-83, 1999.

HAWKINS, M.; NORTON, B. 2009. Critical language teacher education. In: BURNS, A.; RICHARDS, J. (Org.). Cambridge guide to second language teacher education. Cambridge: Cambridge University Press, 2009. p. 30-39.

HOOKS, B. Teaching to transgress: education as the practice of freedom. New York: Routledge, 1994.

JORDÃO, C. M. Conversas com Clarissa Menezes Jordão. In: SILVA, K. A. da; ARAGÃO, R. C. (Org.). Conversas com formadores de professores de linguas: avanços e desafios. Campinas: Pontes Editores, 2013. p. 77-91.

JORGENSEN, M. W.; PHILLIPS, L. J. Discourse analysis as theory and method. London: Sage Publications, 2002. Doi: https://doi.org/10.4135/9781849208871.

LEFFA, V. J. Aspectos políticos da formação do professor de línguas estrangeiras. In: LEFFA, V. J. (Org.). O professor de línguas estrangeiras: construindo a profissão. Pelotas: EDUCAT, 2001. p. 333-355.

MENEZES DE SOUZA, L. M. T. Para uma redefinição de Letramento Crítico: conflito e produção de significação. In: MACIEL, R. F.; ARAÚJO, V. de A. (Org.). Formação de professores de línguas: ampliando perspectivas. Jundiaí: Paco Editorial, 2011. p. 128-140.

MONTE MÓR, W. As políticas de ensino de línguas e o projeto de letramentos. In: NICOLAIDES, C. et al. (Org.). Politica e politicas linguísticas. Campinas: Pontes Editores, 2013a. p. 219-236.

MONTE MÓR, W. Crítica e letramentos críticos: reflexões preliminares. In: ROCHA, C. H.; MACIEL, R. F. (Org.). Lingua estrangeira e formação cidadã: por entre discursos e práticas. Campinas: Pontes Editores, 2013b. p. 31-50.

NORTON, B.; TOOHEY, K. (Ed.). Critical pedagogies and language learning. Cambridge: CUP, 2004. Doi: https://doi.org/10.1017/CBO9781139524834.

NÓVOA, A. (Org.). Vidas de professores. Portugal, Porto Editora, 1991.

NÓVOA, A. (Coord.). Profissão professor. 2. ed. Porto/Portugal: Porto Editora, 1995. 
OLIVEIRA, O. S. de; ZIENTARSKI, C.; DRABACH, N. P.; PEREIRA, S. M. Perspectivas na consolidação do sistema de ensino brasileiro: o desenho da democratização proposto nas leis de diretrizes e bases - Leis 4.024/61 e 9.394/96. Jornal de Políticas Educacionais, Universidade Federal do Paraná n. 7, p. 41-52, 2010. Available at: <http://ojs.c3sl.ufpr.br/ojs/index.php/jpe/article/ view/21862/14298>. Retrieved on: 28 June 2017. ISSN: 1981-1969.

OLIVEIRA, D. A. A reestruturação do trabalho docente: precarização e flexibilização. Educação e Sociedade, Campinas, v. 25, n. 89, p. 1127-1144, 2004.

PENNYCOOK, A. Introduction: critical approaches to TESOL. TESOL Quarterly, Wiley Online Library, v. 33, n. 3, p. 329-348, 1999.

PENNYCOOK, A. Critical Applied Linguistics: a critical introduction. New Jersey: Lawrence Erlbaum Associates, 2001.

PENNYCOOK, A. The myth of English as an international language. In: MAKONI, S.; PENNYCOOK, A. (Org.). Disinventing and reconstituting languages. Clevedon: Multilingual Matters, 2007. p. 90-115.

PESSOA, R. R. Conversa com Rosane Rocha Pessoa. In: SILVA, Kleber A. da.; ARAGÃO, Rodrigo C. (Org.). Conversas com formadores de professores de línguas: avanços e desafios. Campinas: Pontes Editores, 2013. p. 299-306.

PESSOA, R. R. A critical approach to the teaching of English: pedagogical and identity engagement. Revista Brasileira de Linguística Aplicada, Belo Horizonte, v. 14, n. 2, p. 353-372, 2014. Available at: < http://www.scielo.br/pdf/rbla/v14n2/ aop3514.pdf > . Retrieved on: 12 jul. 2017.

PESSOA, R. R.; URZÊDA-FREITAS, M. T. de. Challenges in critical language teaching. TESOL Quarterly, Wiley Online Library, v. 46, n. 4, p. 753-776, 2012.

SANTOS, B. S. Um discurso sobre as ciências na transição para uma ciência pósmoderna. Estudos Avançados, São Paulo, v. 2, n. 2, p. 46-71, 1988. Doi: https://doi. org/10.1590/S0103-40141988000200007.

SANTOS, B. S. Pela mão de Alice: o social e o político na pós-modernidade. 3. ed. São Paulo: Cortez, 1997.

TÍLIO, R. Conversa com Rogério Tílio. In: SILVA, K. A. da; ARAGÃO, R. C. (Org.). Conversas com formadores de professores de línguas: avanços e desafios. Campinas: Pontes Editores, 2013. p. 277-297.

Data de submissão: 21/02/2017. Data de aprovação: 06/07/2017. 